\title{
Combining Ability Analysis for Cured Leaf Yield and its Component Traits in FCV (Flue-Cured Virginia) Tobacco (Nicotiana tabacum L.)
}

\author{
Megha Ganachari*, H.D. Mohan Kumar, B.M. Dushyantha Kumar, \\ S.P. Nataraju and H. Ravindra
}

Department of Genetics and Plant Breeding, College of Agriculture, Shivamogga

University of Agricultural and Horticultural Sciences, Shivamogga-577225, Karnataka, India

*Corresponding author

\section{A B S T R A C T}

\section{Keywords \\ Combining ability, FCV (Flue-Cured Virginia) tobacco, GCA (General combining ability) and SCA (Specific combining ability) \\ Article Info \\ Accepted: \\ 18 January 2019 \\ Available Online: \\ 10 February 2019}

\begin{abstract}
The research was conducted to assess the combining ability in respect to leaf yield and its component characters through 6 × 6 diallel mating design involving thirty hybrids and six parents in FCV tobacco during kharif 2016 at ZAHRS (Zonal Agricultural and Horticultural Research Station), College of Agriculture Shivamogga. Combining ability analysis was carried out for leaf yield and its components in FCV tobacco. Both General combining ability (GCA) and Specific combining ability (SCA) variances were highly significant for almost all the characters. Parents and $\mathrm{F}_{1}$ hybrids differ significantly for GCA and SCA effects for all the characters respectively. Study on the combining ability revealed that the parents Kanchan, FCH-222 and Tobios- 6 were found to be best general combiners for cured leaf yield than others. The highest significant positive SCA effects was observed in the cross $2 \times 4$ followed by $1 \times 3,6 \times 1,1 \times 4$ and $1 \times 5$ for cured leaf yield. These hybrids were found to be suitable for obtaining higher cured leaf yield in FCV tobacco.
\end{abstract}

\section{Introduction}

Tobacco (Nicotiana tabacum L.) is one of the most important non-edible commercial crop in India. In the development of national economy it has been playing a prominent role. Tobacco is called as 'The Golden leaf'. It is one of the members of Solanaceae family and belongs to genus Nicotiana. It is selfpollinated allopolyploid species. It is an amphidiploids $(2 \mathrm{n}=48)$ of Nicotiana sylvestris
$(2 n=24)$ and Nicotiana tomentosa $(2 n=24)$, the wild progenitor species (Gerstel, 1960 and Gerstel, 1963) and are believed to be originated in tropical America (Akehurst, 1981). The quality of tobacco produced in Karnataka light soils (KLS) is on par with the best in the world and is in great demand for export purpose but in Karnataka yield levels of FCV tobacco are lower than the national average. Due to several fold increase in the cost of inputs and labour wages, farmers are 
not able to realize higher profit. The genetic potential of the present cultivated varieties has stagnated at $2000 \mathrm{~kg} / \mathrm{ha}$. Hence, it is desirable to enhance the genetic yield potential of the varieties up to $3000 \mathrm{~kg} / \mathrm{ha}$ through genetic improvement of the crop. Medicinally tobacco is used as a sedative, diuretic, expectorant, discutient and internally only as an emetic, when all other emetics fail. Externally nicotine is used as an antiseptic. Tobacco produces nicotine sulphate which is used as an insecticide. Tobacco is claimed to be miracle crop because of its nature and properties, which is used for range of purpose right from pesticides, narcotics, stimulants and medicinal uses (Narasimha Rao and Krishnamurthy, 2007).

To enhance the present yield levels, it is essential a systemic varietal improvement through hybridization and exploitation of generated variability through recombination breeding. To achieve this, the role of combining ability is important in choosing suitable parents to nick well in the expression of heterosis. Thus the evaluation of genotypes for their nicking ability is a pre-requisite for the final selection of parents in hybridization programme. This is because the per se performance of a parent is not always a true indicator of its potential in hybrid combination. Combining ability gives addition information on nature of gene action which will be helpful to develop efficient crop improvement programme. It is necessary to have detailed information about the desirable parental combination in any breeding programme that can involve a high degree of heterotic response. Top-cross, poly-cross and diallel crossing methods are used for the assessment of variability, combining ability and heterosis. The objectives of this study were to use diallel mating design to determine the general and specific combining abilities for cured leaf yield and its component traits.

\section{Materials and Methods}

During kharif season 2016, investigation was carried out on analysis of combining ability in FCV tobacco (Nicotiana tabacum L.). The experiment on combining ability was conducted in the experimental plot, College of Agriculture, ZAHRS (Zonal Agricultural and Horticultural Research Station), University of Agricultural and Horticultural Sciences, Shivamogga, Karanataka. Shivamogga comes under Southern transition agro climatic zone of Karnataka, (Zone number-7). Geographically, Shivamogga is situated between $13027^{\prime}$ to 140 39' latitude and 740 $37^{\prime} \mathrm{E}$ longitude with an altitude of $650 \mathrm{~m}$ above the MSL. A total rainfall of $1232.8 \mathrm{~mm}$ was received during the year of investigation.

The experimental material for study comprised of thirty $\mathrm{F}_{1}$ populations and their six parents (Bhavya, FCV- Special, Sahyadri, Kanchan, Tobios-6 and FCH-222), where Kanchan is used as a Standard check. These materials were used for genetic analysis of leaf yield and its component traits in FCV tobacco. On the raised seed beds seedlings were grown in the nursery. Length of rows of is $6 \mathrm{~m}$ with spacing of $90 \times 60 \mathrm{~cm}$ and planted in a Simple Lattice Design (SLD) with three replications, during kharif 2016. Crop was raised as per the recommended package of practices. Leaves were harvested by priming method as and when they assume yellowish green colours. The pre and post harvest observations were recorded viz., Days to 50 per cent flowering, Days to maturity, Plant height $(\mathrm{cm})$, Chlorophyll content, Stem girth $(\mathrm{mm})$, Internodal distance $(\mathrm{cm})$, Number of leaves per plant, Specific leaf weight $\left(\mathrm{mg} / \mathrm{cm}^{2}\right)$, Leaf length $(\mathrm{cm})$, Leaf width $(\mathrm{cm})$, Leaf area per plant $\left(\mathrm{dm}^{2}\right)$, Green leaf yield (q/ha), Cured leaf yield (q/ha), Top grade equivalent (q/ha), Reducing sugar (\%) and Nicotine content (\%). 
The mean data collected for each character on individual plant basis for five observational plants was statistically analyzed to work out combining ability for yield and its components. Combining ability analysis was carried out following Model I, Method 1 described by Griffing (1956). Analysis was done using WINDOW stat 9.2 software. Variance due to general combining ability (GCA) of parents and specific combining ability (SCA) of crosses or hybrids were worked out on the procedure developed by Kempthorne (1957).

\section{Results and Discussion}

The knowledge of combining ability provides a useful clue for selection of desirable parents for development of superior hybrids. The ultimate choice of parents to be used in a breeding programme is determined by per se performance and their behaviour in hybrid combination. Some idea on the usefulness of the parents may be obtained from their individual performance, particularly in respect of yield components. It is therefore, necessary to assess genetic potentialities of the parents in hybrid combination through systematic studies in relation to general and specific combining abilities. The combining ability concept was proposed by Sprague and Tatum (1942) in corn, according to them, the general combining ability (GCA) is the comparative ability of the line to combine with other lines. It is deviation of the mean performance of all the crosses involving a parent from overall mean. Specific combining ability (SCA) was defined as the deviation in the performance of specific cross from the performance expected on the basis of general combining ability effects of parents involved in the crosses. A positive general combining ability (GCA) indicates a parent that produces above average progeny, whereas parent with negative GCA produces progeny that performs below average of the population.
Specific combining ability (SCA) can be either negative or positive and sca always refers to a specific cross.

From the Table 1 it is evident that variances due to general combining ability (GCA) were significant for the characters days to maturity, plant height, chlorophyll content, specific leaf weight, stem girth, internodal distance, leaf length, leaf breadth and nicotine content. The SCA variance was found significant for the characters days to 50 per cent flowering, days to maturity, plant height, chlorophyll content, stem girth, internodal distance, leaf length, leaf breadth, leaf area, green leaf yield, cured leaf yield and top grade equivalent (TGE). Whereas the reciprocal variance was significant for all the characters except for the internodal distance, number of leaves per plant, reducing sugar and nicotine content.

Number of leaves per plant is one of the important yield contributing traits in FCV tobacco. The GCA effects of the Parent-1 i.e. Bhavya, Parent-6 i.e. FCH-222 and Parent-2 i.e. FCV-Special were found to be significantly positive in favorable direction, whereas Parent-5 i.e. Tobios-6 was highly significant in the un-favorable direction followed by Parent-3 i.e. Sahyadri and Parent4 i.e. Kanchan (Table 2). Among the thirty hybrids nine of the hybrids exhibited significant positive SCA effects. Two crosses exhibited significant negative SCA effect (Table 3). Similar observations for gca and sca effects were recorded Bronius (1970), Dubey (1976), Patel et al., (2005), Aleksoska and Aleksoski (2012), Ramachandra et al., (2015) and Katba et al., (2017).

Leaf area is one of the important yield contributing traits in FCV tobacco. The GCA effects of the Parent-3 i.e. Sahyadri and Parent-6 i.e. FCH-222 were found to be significantly positive in favorable direction. 
Table.1 Analysis of variance for Combining ability in FCV tobacco

\begin{tabular}{|c|c|c|c|c|c|c|c|c|}
\hline Source & GCA & SCA & Reciprocal & Error & GCA variance & SCA variance & Reciprocal variance & $\begin{array}{l}\text { GCA variance / } \\
\text { SCA variance }\end{array}$ \\
\hline Days to 50 per cent flowering & 21.618 & $66.978 * *$ & $1009.703 * *$ & 13.554 & 0.672 & 53.424 & 26.880 & 0.013 \\
\hline Days to maturity & $115.263 * *$ & $63.768 * *$ & $287.097 * *$ & 5.27086 & 9.166 & 58.498 & 140.913 & 0.157 \\
\hline Plant height (cm) & $171.2981 * *$ & $251.669 * *$ & $250.863^{* *}$ & 2.64888 & 14.054 & 249.021 & 124.107 & 0.056 \\
\hline Chlorophyll Content & $4.51875^{* *}$ & $2.67043 * *$ & $1.46859 *$ & 0.67480 & 0.320 & 1.996 & 0.397 & 0.161 \\
\hline Specific leaf weight $\left(\mathrm{mg} / \mathrm{cm}^{2}\right)$ & $0.47077 * *$ & 0.21876 & $0.55233 * *$ & 0.13970 & 0.028 & 0.079 & 0.206 & 0.349 \\
\hline Stem girth $(\mathbf{m m})$ & $0.71504 *$ & $2.10840 * *$ & $1.81746^{* *}$ & 0.26067 & 0.038 & 1.848 & 0.778 & 0.020 \\
\hline Internodal distance (cm) & $0.88409 * *$ & $0.74271 * *$ & 0.09431 & 0.12295 & 0.0634 & 0.6197 & -0.0143 & 0.1023 \\
\hline Number of leaves/plant & 0.32440 & 0.31885 & 0.75630 & 0.44419 & -0.010 & -0.125 & 0.156 & 0.080 \\
\hline Leaf length $(\mathrm{cm})$ & $10.36416 * *$ & $6.68076 * *$ & $10.55274 * *$ & 2.53148 & 0.653 & 4.419 & 4.011 & 0.157 \\
\hline Leaf breadth (cm) & $2.23274^{*}$ & $2.31264 * *$ & $4.61659 * *$ & 0.71178 & 0.127 & 1.601 & 1.952 & 0.079 \\
\hline Leaf area $\left(\mathbf{d m}^{2}\right)$ & 7172.152 & $12236.773 * *$ & $10757.776^{*}$ & 5280.141 & 157.667 & 6956.632 & 2738.817 & 0.023 \\
\hline Green leaf yield (q/ha) & $13623.267 *$ & $35952.59 * *$ & $16917.005^{* * *}$ & 7164.086 & 538.265 & 12001.245 & 4876.400 & 0.045 \\
\hline Cured leaf yield (q/ha) & $297.04^{*}$ & $526.87 * *$ & $333.64 * *$ & 102.34 & 7.7510 & 172.818 & 70.221 & 0.045 \\
\hline Top grade equivalent (q/ha) & 106.93 & $189.67 * *$ & $120.11 * *$ & 36.84 & 2.790 & 62.214 & 25.279 & 0.045 \\
\hline Reducing Sugar (\%) & 0.84722 & 1.18009 & 0.46357 & 0.71248 & 0.011 & 0.468 & -0.124 & 0.024 \\
\hline Nicotine Content (\%) & $0.00888^{*}$ & 0.00219 & 0.00270 & 0.00321 & 0.00047 & -0.001 & 0.00025 & -0.465 \\
\hline
\end{tabular}

Where GCA - General combining ability, SCA - Specific combining ability.

* - Significant at 5 per cent probability, ** - Significant at 1 per cent probability.

Table.2 General combining effects for six parents in FCV tobacco

\begin{tabular}{|c|c|c|c|c|c|c|c|c|c|c|c|c|c|c|c|c|}
\hline Parents & $\begin{array}{c}\text { Days to } \\
50 \text { per } \\
\text { cent } \\
\text { flowering }\end{array}$ & $\begin{array}{c}\text { Days to } \\
\text { maturity }\end{array}$ & $\begin{array}{c}\text { Plant } \\
\text { height } \\
(\mathrm{cm})\end{array}$ & $\begin{array}{l}\text { Chlorophyl } \\
\text { I Content }\end{array}$ & $\begin{array}{c}\text { Specific } \\
\text { leaf } \\
\text { weight } \\
\left(\mathrm{mg} / \mathrm{cm}^{2}\right)\end{array}$ & $\begin{array}{l}\text { Stem } \\
\text { girth } \\
(\mathrm{mm})\end{array}$ & $\begin{array}{l}\text { Internod } \\
\text { al } \\
\text { distance } \\
(\mathrm{cm})\end{array}$ & $\begin{array}{c}\text { Number } \\
\text { of leaves } \\
\text { per } \\
\text { plant }\end{array}$ & $\begin{array}{c}\text { Leaf } \\
\text { length } \\
(\mathrm{cm})\end{array}$ & $\begin{array}{c}\text { Leaf } \\
\text { breadth } \\
(\mathrm{cm})\end{array}$ & $\begin{array}{c}\text { Leaf area } \\
\left(\mathbf{d m}^{2}\right)\end{array}$ & $\begin{array}{c}\text { Green } \\
\text { leaf } \\
\text { yield } \\
\text { (q/ha) }\end{array}$ & $\begin{array}{c}\text { Cured } \\
\text { leaf yield } \\
\text { (q/ha) }\end{array}$ & $\begin{array}{l}\text { Top grade } \\
\text { equivalent } \\
\text { (q/ha) }\end{array}$ & $\begin{array}{c}\text { Reducing } \\
\text { Sugar } \\
(\%)\end{array}$ & $\begin{array}{l}\text { Nicotine } \\
\text { Content } \\
(\%)\end{array}$ \\
\hline Bhavya & $-2.279 * *$ & $-2.465 * *$ & -1.533 & $0.3369 *$ & $-0.310 * *$ & -0.105 & -0.1125 & $0.269 * *$ & $-0.850 *$ & $-0.722 * *$ & $-3.0373 * *$ & -1.9585 & -0.2927 & -0.1756 & 0.053 & $-0.028 * *$ \\
\hline FCV-Special & $1.513^{* *}$ & $0.919 *$ & $-1.972 *$ & -0.079 & $0.145^{*}$ & -0.015 & $-2.119 * *$ & $0.024 *$ & 0.100 & 0.106 & 1.1187 & $-5.1048 *$ & $-0.7657 *$ & $-0.4594 *$ & $-0.104^{*}$ & $-0.029 * *$ \\
\hline Sahyadri & $1.174^{*}$ & -0.087 & $-2.617 * *$ & $-1.002 * *$ & -0.108 & -0.060 & $0.4807^{*}$ & $-0.098^{*}$ & $1.100 * *$ & $0.333 * *$ & $2.7620 * *$ & -1.3463 & -0.1804 & -0.1082 & $0.191 *$ & $0.012 *$ \\
\hline Kanchan & 0.088 & $-4.081 * *$ & $-3.356 * *$ & $0.791 * *$ & $-0.201 *$ & -0.184 & 0.0007 & $-0.220 * *$ & $-\overline{1.239 * *}$ & $0.378^{* *}$ & $-3.052 * *$ & $3.5523 * *$ & $0.5028 * *$ & $0.3017 * *$ & $-0.404 * *$ & 0.005 \\
\hline Tobios-6 & -0.156 & $4.871 * *$ & $3.711 * *$ & $0.193 *$ & -0.162 & -0.122 & $-0.124 *$ & $-0.031 *$ & -0.028 & 0.217 & 1.0048 & $1.8633^{*}$ & $0.3002 *$ & $0.1801 *$ & $0.361 * *$ & -0.003 \\
\hline FCH-222 & -0.340 & $0.844^{*}$ & $5.767 * *$ & -0.273 & 0.017 & $0.484^{* *}$ & $-0.121^{*}$ & $0.057 *$ & $0.917 *$ & -0.311 & $1.2041^{*}$ & $2.9941^{*}$ & $0.4358 *$ & $0.2615^{*}$ & -0.098 & $0.043^{* *}$ \\
\hline (gi) $\mathrm{SEm} \pm$ & 0.9702 & 0.6051 & 0.4288 & 0.2164 & 0.0985 & 0.1345 & 0.0924 & 0.1756 & 0.4192 & 0.2223 & 1.9148 & 2.2304 & 0.2676 & 0.1605 & 0.2224 & 0.0149 \\
\hline CD at $5 \%$ & 3.864 & 2.409 & 1.708 & 0.862 & 0.392 & 0.536 & 0.368 & 0.699 & 1.670 & 0.885 & 7.6257 & 8.8825 & 1.0659 & 0.6395 & 0.886 & 0.059 \\
\hline CD at $1 \%$ & 6.060 & 3.779 & 2.679 & 1.352 & 0.615 & 0.840 & 0.578 & 1.097 & 2.619 & 1.389 & 11.9615 & 13.9330 & 1.6719 & 1.0031 & 1.389 & 0.093 \\
\hline
\end{tabular}

*- Significant at 5 per cent probability, ${ }^{* *}$ - Significant at 1 per cent probability 
Table.3 Number of parents and crosses showing significant GCA and SCA effects to the positive and negative directions and ranges

\begin{tabular}{|c|c|c|c|c|c|c|c|c|c|}
\hline \multirow[t]{2}{*}{ Sl No. } & \multirow[t]{2}{*}{ Characters } & \multicolumn{4}{|c|}{ No. of parents with GCA effects } & \multicolumn{4}{|c|}{ No. of hybrids with SCA effects } \\
\hline & & Positive & Negative & Total & Range & Positive & Negative & Total & Range \\
\hline 1 & Days to 50 per cent flowering & 2 & 1 & 3 & -2.279 to 1.513 & 8 & 8 & 16 & -40.007 to 11.829 \\
\hline 2 & Days to maturity & 3 & 2 & 5 & -4.081 to 4.871 & 8 & 14 & 22 & -20.73 to 9.7 \\
\hline 3 & Plant height $(\mathrm{cm})$ & 2 & 4 & 6 & -3.356 to 5.767 & 12 & 14 & 26 & -27.233 to 19 \\
\hline 4 & Chlorophyll Content & 3 & 1 & 4 & -1.002 to 0.791 & 7 & 5 & 12 & -1.5933 to 2.26 \\
\hline 5 & Specific leaf weight $\left(\mathrm{mg} / \mathrm{cm}^{2}\right)$ & 1 & 2 & 3 & -0.31 to 0.145 & 11 & 5 & 16 & -0.9 to 0.6866 \\
\hline 6 & Stem girth $(\mathrm{mm})$ & 1 & 0 & 1 & -0.184 to 0.484 & 11 & 10 & 21 & -1.914 to 1.671 \\
\hline 7 & Internodal distance (cm) & 1 & 3 & 4 & -2.119 to 0.4807 & 6 & 6 & 12 & -0.9046 to 0.51 \\
\hline 8 & Number of leaves/plant & 2 & 4 & 6 & -0.22 to 0.269 & 9 & 2 & 11 & -0.7 to 1.4 \\
\hline 9 & Leaf length $(\mathrm{cm})$ & 2 & 2 & 4 & -1.239 to 1.1 & 5 & 9 & 14 & -5.833 to 1.95 \\
\hline 10 & Leaf breadth $(\mathrm{cm})$ & 2 & 1 & 3 & -0.722 to 0.378 & 8 & 11 & 19 & -3.2 to 2.133 \\
\hline 11 & Leaf area $\left(\mathrm{dm}^{2}\right)$ & 2 & 2 & 4 & -3.0525 to 2.7620 & 7 & 9 & 16 & -13.84 to 11.194 \\
\hline 12 & Green leaf yield (q/ha) & 3 & 1 & 4 & -5.1048 to 3.5523 & 7 & 7 & 14 & -28.454 to 8.1662 \\
\hline 13 & Cured leaf yield (q/ha) & 3 & 1 & 4 & -0.7657 to 0.5028 & 12 & 7 & 19 & -4.2201 to 1.445 \\
\hline 14 & Top grade equivalent (q/ha) & 3 & 1 & 4 & -0.4594 to 0.3017 & 8 & 10 & 18 & -2.5321 to 0.8187 \\
\hline 15 & Reducing Sugar (\%) & 2 & 2 & 4 & -0.404 to 0.361 & 11 & 7 & 18 & -1.232 to 0.954 \\
\hline 16 & Nicotine Content (\%) & 2 & 2 & 4 & -0.029 to 0.043 & 5 & 5 & 10 & -0.08 to 0.072 \\
\hline
\end{tabular}


Table.4 Performance of top ten superior experimental hybrids over check with respect to per se value of sixteen characters in FCV tobacco

\begin{tabular}{|c|c|c|c|c|c|c|c|c|c|c|c|c|c|c|c|c|}
\hline $\begin{array}{c}\text { Experimental } \\
\text { Hybrids }\end{array}$ & DFF & DM & PH & $\mathrm{CC}$ & SLW & SG & ID & NLP & $\mathbf{L L}$ & LB & LA & GLY & CLY & TGE & $\mathbf{R S}$ & NIC \\
\hline $6 \times 1$ & 129.53 & 189.06 & 189.93 & $15.01 * *$ & 4.98 & 23.89 & $4.20 * *$ & 12.26 & 47.86 & 25.46 & 94.366 & 141.7093 & 17.0051 & 10.2030 & 12.6 & 1.00 \\
\hline $3 \times 1$ & $119.00 * *$ & $162.06 * *$ & 163.33 & $15.22 * *$ & 5.99 & 24.20 & $4.03 * *$ & $13.26 * *$ & 49.13 & $27.26 * *$ & $112.486 * *$ & 139.7407 & 16.7688 & 10.0613 & 11.2 & 1.07 \\
\hline $2 \times 1$ & $108.06^{* *}$ & 170.26 & 147.66 & 14.51 & 6.01 & 24.70 & $4.03 * *$ & $13.33 * *$ & 39.46 & 25.93 & 88.376 & 137.4793 & 16.4975 & 9.8985 & 11.6 & 1.01 \\
\hline $4 \times 1$ & 124.36 & $158.40^{* *}$ & 161.73 & $14.63 * *$ & 5.08 & 24.01 & $4.04 * *$ & 11.80 & 49.53 & $27.20 * *$ & 100.389 & 136.9820 & 16.4378 & 9.8627 & 12.6 & 0.98 \\
\hline $6 \times 2$ & 133.66 & 183.80 & 185.86 & 13.30 & 5.52 & 25.87 & $4.09 * *$ & $12.53 * *$ & 48.26 & 24.33 & 93.517 & 134.3467 & 16.1216 & 9.6729 & 11.8 & 1.10 \\
\hline $2 \times 4$ & $114.76^{*}$ & $148.80 * *$ & 170.53 & $16.20 * *$ & 5.55 & 23.92 & $4.04 * *$ & $12.53 * *$ & 45.73 & $27.33 * *$ & 98.941 & 133.8807 & 16.0656 & 9.6394 & 12.6 & 1.04 \\
\hline $5 \times 1$ & 124.60 & 170.73 & 173.33 & $15.30 * *$ & 5.23 & 25.60 & $3.86 * *$ & 11.73 & 49.60 & $27.13 * *$ & 100.338 & 133.0213 & 15.9625 & 9.5775 & 13.7 & 0.95 \\
\hline $5 \times 3$ & 124.86 & 185.66 & 166.86 & 12.98 & 4.54 & 23.31 & $3.96 * *$ & $12.66 * *$ & 47.66 & $26.53 * *$ & 101.142 & 130.3627 & 15.6435 & 9.3861 & 12.1 & 0.94 \\
\hline $1 \times 4$ & 127.5 & $157.63^{* *}$ & 170.46 & $17.01 * *$ & 5.80 & 25.44 & $4.16 * *$ & $14.60 * *$ & 37.86 & 22.06 & 76.335 & 129.1413 & 15.4969 & 9.2981 & 12.4 & 1.03 \\
\hline $1 \times 5$ & $118.63 * *$ & $148.33^{* *}$ & 174.40 & $16.08 * *$ & 6.14 & 22.17 & $3.99 * *$ & $13.26 * *$ & 43.13 & 23.66 & 86.380 & 128.378 & 15.4053 & 9.2432 & 12.6 & 1.04 \\
\hline Mean & 122.496 & 167.473 & 170.409 & 15.024 & 5.484 & 24.311 & 4.04 & 12.796 & 45.822 & 25.686 & 95.227 & 134.5042 & 16.1405 & 9.6843 & 12.32 & 1.013 \\
\hline $\begin{array}{c}\text { Check } \\
\text { (Kanchan) }\end{array}$ & 123.333 & 172.467 & 150.40 & 16.80 & 5.68 & 25.41 & 4.54 & 11.80 & 44.20 & 26.13 & 56.043 & 122.397 & 14.688 & 8.813 & 10.5 & 1.02 \\
\hline
\end{tabular}

* - Significant at 5 per cent level, ** - Significant at 1 per cent level

Where,

DFF - Days to 50 per cent flowering

DM - Days to maturity

$\mathrm{PH}$ - Plant height $(\mathrm{cm})$

CC - Chlorophyll Content

SLW - Specific leaf weight $\left(\mathrm{mg} / \mathrm{cm}^{2}\right)$

$\mathrm{SG}$ - Stem girth (mm)
ID - Internodal distance (cm)

NLP - Number of leaves plant

LL - Leaf length (cm)

LB - Leaf breadth (cm)

LA - Leaf area $\left(\mathrm{dm}^{2}\right)$

GLY - Green leaf yield (q/ha)
CLY - Cured leaf yield (q/ha)

TGE - Top grade equivalent (q/ha)

RS - Reducing Sugar (\%)

NIC - Nicotine Content (\%) 
The Parent-1 i.e. Bhavya and Parent-4 i.e. Kanchan were highly significant in the unfavorable direction (Table 2). Nine crosses exhibited significant negative sca effect (Table 3). Similar results of GCA and SCA effects by Dubey (1976), Patel et al., (2005) and Gopal et al., (2016).

Total Cured leaf yield is one of the important yield contributing traits in FCV tobacco. Out of six parents, Parent-4 i.e. Kanchan, Parent-6 i.e. $\mathrm{FCH}-222$ and Parent-5 i.e. Tobios-6 exhibited significant positive GCA effects. Whereas Parent-2 i.e. FCV-Special exhibited significant negative effect (Table 2). The significant SCA effects were observed for nineteen hybrids among the thirty crosses, of which twelve hybrids exhibited positive and the remaining seven hybrids exhibited negative effects for cured leaf yield. Similar reports made by Dubey (1976), Jadeja et al., (1984), Patel et al., (2005), Lohitha et al., (2010), Aleksoska and Aleksoski (2012), Ramachandra et al., (2015), Gopal et al., (2016) and Katba et al., (2017).

The combining ability studies indicated high proportions of SCA variances than GCA variances. Study on combining ability variance revealed that non-additive gene action was predominant for all the traits studied and these traits can be improved for combining ability through recurrent selection schemes or heterosis breeding. These hybrids would be advantageous for production and quality improvement.

The crosses $6 \times 1,3 \times 1,2 \times 1,4 \times 1,6 \times 2,2$ $\mathrm{x} 4,5 \times 1,5 \times 3,1 \times 4$ and $1 \times 5$ were the superior hybrids selected for total cured leaf yield since these crosses exhibited significant gca and sca effects for total cured leaf yield (Table 4). Ten promising single cross hybrids identified for leaf yield (cured leaf yield) need to be tested in multi-locations trials for their stability across locations/seasons on large scale basis before their commercial utilization. Promising single crosses having good general combining parents can be used for further improvement of parents in later generations. Selected parents with desirable per se and combining ability effect can be used in multiple crossing schemes to recombine different productivity components.

\section{References}

Akehurst, B.C., 1981, Tobacco. New York: Longman.

Aleksoska, A. K. and Aleksoski, J., 2012, Investigations of combining abilities in diallel set of varieties belonging to several tobacco types. Agric. conspec. sci., 77(4): 203-206.

Bronius P., 1970, Diallel analysis of crosses between flue-cured and burley tobacco cultivars. Can. J. Gen. Cytol., 12(3): 484-489.

Dubey, R. S., 1976, Combining ability in cigar filler tobacco. Ind. J. Gen. Pl. Bred., 35(1): 76-82.

Gerstel, D. U., 1963, Segregation in new allopolyploids of Nicotiana. II. Discordant ratios from individual loci in 6x (N. tabacum x N. sylvestris). Gen, 48: 677-689.

Gopal, V. Huchhadiya, Patel, B. R., Dixita, K. Patel, and Patel, J. R., 2016, Combining ability and gene action for cured leaf yield, its components and quality traits in bidi tobacco (Nicotiana tabacum L.). Int. J. Sci. Environ. Tech., 5(4): 18611873.

Griffing, B., 1956, A generalized treatment of diallel crosses in quantitative inheritance. Heredity, 10: 31-50.

Jadeja, G. C., Jaisani, B. G. and Patel, G. J., 1984, Diallel study of some economic traits of bidi tobacco. Tob. Res., 10(1): 59-63.

Katba, P. J., Hadiya, R. G., Kapadia, V. N., Patel, D. C. and Patel, A. D., 2017, Genetic studies on yield and 
pharmaceutical quality parameters in tobacco (Nicotiana rustica L.). J. Pharma. Phytochem., 6: 399-404.

Kempthorne, O., 1957, An Introduction to Genetics Statistics, John Wiley and Sons, New York, 1st Edition, pp. 456471.

Lohitha, K. S., Rangaiah, S., Devaraja, C., Pranesh, K. J., Ramesh, S. and Mohan Rao, A., 2010, Studies on general combining ability, specific combining ability, heterosis and their relationship in FCV tobacco (Nicotiana tabacum L.). Gregor Mendel Found. J., 1: 45-49. Narasimha Rao, C. V. and Krishnamurthy, V., 2007, Tobacco plant: A source of pharmaceutical and industrial products. Invention Intelligence 3-12.

Patel, J. S., Sundar, R. M., Patel, N. M., Patel, M. R. AND PARMAR, D. J., 2005, Combining ability analysis in tobacco (Nicotiana tabacum L.). Prog. Agric., 5: 114-116.

Ramachandra, R. K., Nagappa B. H and Anjenaya Reddy B. 2015. Heterosis studieson yield and quality parameters in bidi tobacco. J. Bio. Innov., 4(4): 126-134.

Sprague, G. F. and Tatum, L. A., 1942, General Vs specific combining ability in single crosses of corn. Agron. J., 34: 923-932.

\section{How to cite this article:}

Megha Ganachari, H.D. Mohan Kumar, B.M. Dushyantha Kumar, S.P. Nataraju and Ravindra, H. 2019. Combining Ability Analysis for Cured Leaf Yield and its Component Traits in FCV (Flue-Cured Virginia) Tobacco (Nicotiana tabacum L.). Int.J.Curr.Microbiol.App.Sci. 8(02): 2306-2313. doi: https://doi.org/10.20546/ijcmas.2019.802.269 